\title{
RAPE SHIELD LEGISLATION: RELEVANCE, PREJUDICE AND JUDICIAL DISCRETION
}

\author{
PEGGY KOBLY*
}

This article analyzes sexual assanll legislation as it stands since the Seaboyer case. Through a discussion of the legislation leading up to "rape shield" lau's and the accompanying case law' Kobly reveals the strengths and weaknesses of Parliament's effort to effectively handle the problem of seitual assandt against women. Ultimately. Kobly conc/udes that legislation which creates blanket excltusioms. such as the legislation considered in Seaboyer, is indeed unconstitutional and that the proper way o ensure only relevam. probative issues are considered in sexul assault cases is to encourage an antumdinal change within society so as to eliminate the negative and pornographic myths and stereotypes that have developed about wome'n and sexuality. According to Kobly. once these have be'n eliminated. judges should be able to properly exercise their discretion to control what occurs within the courtroom so as t) encourage sexwal assants victims to step forward and trust the judicial system.
Le mésem article analyse les lois traitam d'agression sexuclle telles qu' elles existent depuis le cas Seabover. A travers une discussion de la législation qui conduit atux lois sutr la protection comtre le viol et an droit jurisprudentiel qui les accompagne. Kobly révele les points forts et les faiblesses des efforts que le Parlement a fournis pour traiter efficacement du problème des agressions sexuclles perpétrées contre les femmes. Finalement. Kobly conclut que les lois qui créent des exclusions globales, comme dans le cas Scaboyer. som en fait inconstituriomelles et que la fason d'assurer que seules les questions pertinemtes et probantes seromt somlevées dans les cas de ce genre, sorail de promonusoir un changement d' antinude dans la société. "l de combatrie les mythes ef sterionges négatifs ef pornographiques qui circulent an sujet des femme's ef de la sevwalité. Selon Kobly, quand ces idées fausses aurom été élimincés, les juges delraient pounoir evercer leur autorific correctement pour controbler ce qui sc passe au tribunal et encourager les victimes à dénoncer leurs agressears et à faire confiance ant systeme judiciaire.

\section{TABLE OF CONTENTS}

I. LEGISLATIVE HISTORY . . . . . . . . . . . . . . . . . . . 989

A. COMMON LAW .................. 989

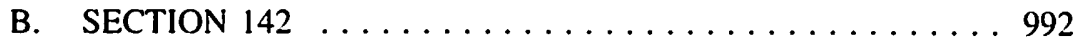

C. SECTION $276 \ldots \ldots \ldots \ldots \ldots \ldots \ldots \ldots \ldots \ldots \ldots$

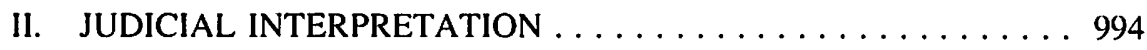

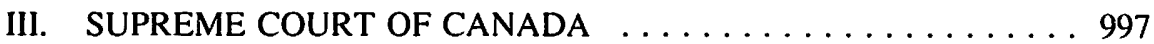

A. RELEVANCE . . . . . . . . . . . . . . . . . . . . . 997

B. PREJUDICE .................... 1000

C. CONSTITUTIONAL ISSUES .............. 1001

IV. PRINCIPLES OF VALID RAPE

SHIELDING PROVISIONS . . . . . . . . . . . . . . . . . . . 1004

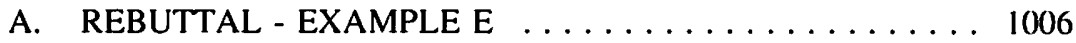

B. IDENTITY - EXAMPLE A ............... 1006

C. BIAS AND MOTIVE TO FABRICATE -

EXAMPLE B

The author is a Research Assistant at the firm of de Villars Jones. Edmonton and will be clerking for the Court of Queen's Bench and the Court of Appeal of Alberta, 1993-94. 


\section{HONEST BUT MISTAKEN BELIEF -

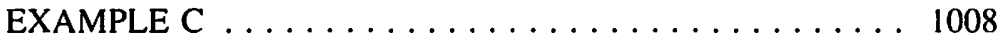

E. SIMILAR ACT EVIDENCE -

EXAMPLE D . . . . . . . . . . . . . . . . . . 1010

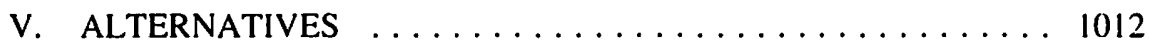

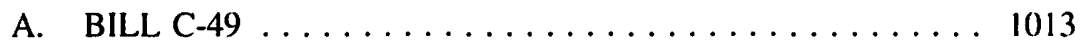

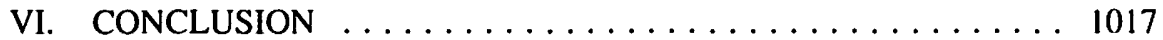

Of every four Canadian women. experts estimate. one will be sexually assaulted during her life. On, average three sexual assialts are reported every hour in Canada. As well, Iwo women a week die at the hands of a current or former husband or lover... (W)omen are vocally insisting. with great determination and growing political force, that the carnage end.'

The growing anger, fear, and frustration with what has been called the "men's war against women"2 has led to changes in the law and in its application. Police forces and prosecutors have begun to recognize the seriousness of domestic violence, and judges have been encouraged to ensure that sentencing and bail and parole requirements are appropriate." Amendments to the Criminal Code have removed rape and other sexual assault crimes from being morals offenses and have incorporated them into offenses against the person, reflecting the realization that these crimes are acts of violence. The legislature has also made two attempts to alter the common law rules of evidence governing the admissibility of evidence in regards to the previous sexual history of the complainant in a rape case. The first so-called "rape shield" law, s. 142 of the Criminal Code, ${ }^{+}$was judicially interpreted so broadly that it resulted in even less protection for the complainant. ${ }^{5}$ To remedy this approach, the legislature enacted ss. 246.6 and 246.7 (now ss. 276 and 277), ${ }^{6}$ which deal with the admissibility of the complainant's previous sexual history and sexual reputation. These sections have been attacked constitutionally as being contrary to sections 7 and 11(d) of the Canadian Charter of Rights and Freedoms, ${ }^{7}$ and in August of 1991, the Supreme Court of Canada in Seaboyer ruled that s. 276, but not s. 277, was unconstitutional.

\section{LEGISLATIVE HISTORY}

\section{A. COMMON LAW}

At common law, the prior sexual history of the complainant was admissible on two grounds, consent and credibility. It was thought that an unchaste woman was more likely

\footnotetext{
"Women in Fear," Macleans (11 November 1991) 26.

Ibid. at 26.

Ibid. at 28.

R.S.C. 1970 . c. C-34.

Re: Seaboyer v. The Queen: Re Gayme and the Queen. 119911 2 S.C.R. 577 at 671 |hereinafter cited as Seabover $]$. R.S.C. 1985, c. C-46.

Part 1 of the Constitution Acr, 1982 being schedule B of the Canada A(r. 1982, (U.K.), 1982, C. II. Ihereinafter cited as the Chatter|.
} 
to have consented and was also more likely to lie. Myths about women and women's sexuality had a profound effect upon what the courts were willing to admit as relevant evidence. The often quoted comment from Wigmore typified the inherent prejudice imbedded in the common law rules.

Modern psychiatrists have amply studied the behaviour of errant young girls and women coming before the courts in all sorts of cases. Their psychic complexes are multifarious, distorted partly by inherent defects. partly by diseased derangements or abnomal instincts, partly by bad social environment, partly by temporary physiological or emotional conditions. One form taken by these complexes is that of contriving false charges of sexual olfenses by men. ${ }^{*}$

Dean Wigmore further argued that rape complainants should submit to psychiatric assessment to determine whether their accusations were "the product of a psychological predisposition for fabrication."' This fear of women making false rape charges against innocent men reverberates throughout the history of the common law rules and their legislative successors. Sir Matthew Hale, Lord Chief Justice of the King's Bench, argued that "rape is an accusation easy to be made, hard to be proved, and harder to be defended by the party accused though ever so innocent."11"

In contemporary literature, Professor D.W. Elliot, quoted by Elizabeth Sheehy, describes a variety of scenarios that reflect what Sheehy calls themes of "indiscriminate female sexuality, of treachery and extortion, and of women's willingness to lie and incriminate men in order to avoid responsibility for their own sexuality." "I Other myths embedded in common law rules include the myth that women fantasize rape, that women are fickle, that they are too emotional to be reliable witnesses, and the myth that their sexual behaviour reflects their character.

Evidence that was considered to be relevant to the issue of consent included evidence of prior sexual conduct with the accused and evidence of a reputation that the accused was a prostitute or guilty of "flagrant sexual misconduct."12 The Report of the FederallProvincial Task Force on Uniform Rules of Evidence $(1982)^{1.3}$ suggested that evidence of specific incidents of prostitution, opinion evidence that the complainant was a prostitute, and evidence that the woman habitually submitted her body to different men, for pay or not, ${ }^{14}$ were also considered to be relevant to the issue of consent at common

x. Wigmore. Evidence in Trials at Common Law, Vol. 3A (1970) at 376. Iquoted by L'Heureux-Dube, J. in Seaboyer at 231.

4. A.J. Soshnick, "The Rape Shicld Paradox: Complainant Protection Amidst Oscillating Trends of State Judicial Interpretation" 76 Journal of Criminal Law and Criminology 644 at 650.

10. Ihid. at 650.

11. E. Sheehy, "Canadian Judges and the Law of Ratpe: Should the Charter Insulate Bias?" 21 Ottawa L.R. 151 at 167.

12. D.M. Paciocco, "The Charter and the Rape Shield Provisions of the Criminal Code: More About Relevance and the Constitutional Exemptions Doctrine" (1989) 21 Ottawa L.R. 119.

11. Quoted by L'Heureux-Dube, J. in Scaboyer at 666.

14. This scenario is recurrent. See Re Seaboyer and the Que'n: Re Gayme and the Queen (1987), 37 C.C.C. (3d) 53, 61 O.R. (2d) 290, 58 C.R. (3d) 289 (C.A.) [hereinafter Seaboyer (C.A.) cited to C.C.C.]. Also quoted in Paciocco's article but reported as fact rather than as hypothetical. 
law. Because these were considered matters relevant to consent, and thus to a material fact in issue, the complainant was compelled to answer, and the defence could introduce evidence to contradict her denial or to prove the accusations. A complainant's sexual history was also considered to be relevant to her credibility. As a collateral issue, her answers could not be rebutted, and the trial judge exercised a certain amount of discretion as to whether the witness must answer.

In the Canadian context, the leading case to set out the common law principles was Laliberte v. The Queen. ${ }^{15}$ The Supreme Court held that the accused had the right to ask questions about the complainant's past sexual activity, but the complainant could not be compelled to answer unless the judge in his discretion determined that the issue was relevant to a material issue, usually consent. In practice the judges gave considerable leeway to the accused, and questions ranged from whether the complainant was on the pill, ${ }^{16}$ to broad ranging question about lifestyle, ${ }^{17}$ to questions that could be humiliating and degrading. ${ }^{18}$

Studies consistently have shown that the admission of such evidence clearly prejudices a trier of fact and makes it more likely that the complainant will not be believed." Among the studies quoted by L'Heureux-Dube, J. in Seaboyer was a Canadian study by $\mathrm{K}$. Catton which found that the more information received about the sexual history of the complainant, whether this information was confirmed or denied, the greater the decrease in the perceived guilt of the accused. ${ }^{211}$ This is due, it would seem, to the entrenchment of myth and stereotype that exists at all levels of society. Even in an age when these myths have supposedly been rejected, comments from judicial and lay sources frequently indicate that they are deeply built into the fabric of how the truth is perceived. The stereotypical rape, that is the rape that is most likely to be believed to be rape, is a sudden violent attack by a stranger in a deserted public place, upon a "good" woman, young and chaste, or married and virtuous. The other rape, described by Susan Estrich in Real Rape: How the Legal System Victimizes Women Who Say No, occurs when the rapist knows his victim, acts alone, and does not use a weapon or brutal violence. ${ }^{21}$ It is this kind of rape where the perception of the victim's character becomes more important than any evidence relating to the character of the accused. The effect of the rules in combination with the traditional ideology shifts "the focus of a criminal trial from an inquiry into the conduct of the offender to that of the moral worth of the complainant."22

(1877). I S.C.R. 117.

C. Boyle. "Section 142 of the Criminal Code: A Trojan Horse?" (1981) 23 Criminal L.Q. 253 at 264. lbid. al 255.

S. Murthy. "Rejecting Unreasonable Sexual Expectations: Limits on using a Rape Victim's Sexual History to Show the Defendant 's Mistaken Belief in Consent" (1991) 79 California Law Review 541 at 562 .

Seabover, supra note 5 at 659-65.

K. Catton. "Evidence Regarding the Prior Sexual History of an Alleged Rape Victim: Its Effect on the Perceived Guilt of the Accused" (1975) 33 U.T. Fac. L. Rev. 165).

(Cambridge: Harvard University Press, 1987).

H. Galvin, "Shielding Rape Victims in the State and Federal Courts: A Proposal for the Second Decade" (1986) 70 Minn. L. R. 763 at 793. 


\section{B. SECTION 142}

Among other common law rules unique to sexual assault cases was the requirement of corroboration. Based again on the inherent unreliability of the complainant's testimony and the belief in the myth that women are prone to false accusations of rape, a complainant's testimony had to be corroborated for a conviction. This rule was later relaxed such that a trial judge was required to warn a jury of the dangers of convicting on the basis of uncorroborated testimony. Eventually, this rule was incorporated into the Criminal Code. In response to criticism of the common law rules and the corroboration warning, the Criminal Code was revised:2.3

142.(1) Where an accused is charged with an offence under section 144 or 145 or subsection 146(1) or 149(1), no question shall be asked by or on behalf of the accused as to the sexual conduct of the complainant with a person other than the accused unless

(a) reasonable notice in writing has been given to the prosecutor by or on behalf of the accused of his intention to ask such question together with particulars of the evidence sought to be adduced by such question and a copy of such notice has been filed with the clerk of the court: and

(b) the judge, magistrate or justice, after holding a hearing in camera in the absence of the jury. if any, is satisfied that the weight of the evidence is such that to exclude it would prevent the making of a just determination of an issue of fact in the procecdings. including the credibility of the complainant. ${ }^{24}$

Although the purpose of the legislation was to protect the complainant from the "fishing expeditions" of the defence, the courts interpreted it in such a way as to provide even less protection. In Forsythe v. The Queen, ${ }^{25}$ the Supreme Court held that the complainant was a compellable witness for the accused at the in camera hearing. It further interpreted the section as meaning that the credibility of the complainant was now a material issue: thus, she was no longer free to refuse to answer questions about her sexual misconduct, and the defence was free to lead evidence to contradict the testimony.

The court in Forsythe determined that there was a trade-off in rights. The complainant could be protected, at the discretion of the judge, from questioning about her previous sexual experience, but then it would be necessary for the complainant to be a compellable witness at the in camera hearing so that the judge could determine if the evidence could be adduced in open court. If the judge found that the evidence was necessary to "the just determination of an issue of fact in the proceeding, including the credibility of the witness," then the accused was able to insist upon an answer, and, even though the evidence may have only been relevant to credibility, he was not bound by the collateral issue rule and could adduce evidence to rebut the testimony. The court suggested that the purpose of s. 142 was to alleviate the complainant's trauma and humiliation caused by an inquiry into her past sexual conduct, and that the section then balanced this "concession" by providing something for the accused.

23. Criminal Law Amendmem Act, 1975, S.C. 1974-75-76, c. 93, s. 8.

24. R.S.C. 1970 , c. C-34 as amended by 1974-75-76, c.93, s.8.

25. [1980] 2 S.C.R. 268. 
The provision...appears...to balance the interests of an accused because, under the prior law, a denial of sexual misconduct with others precluded any further inquiry into what was considered to be a collateral issuc... The accused, in making his defence, is not limited to cross-examining the complainant to cxpose the falsity of a denial of sexual encounters...but may put forward other witnesses...to impugn the credibility of the complainant."2th

Christine Boyle argued that this approach ignored the purpose of the legislation, that is to address the problem of under reporting and low conviction rates, and that what was required from the legislature was some guidelines on relevance. ${ }^{27}$ The effect of the decision was to frustrate the goals of the legislature, and to further cloud the issue of what would constitute relevance in the case of sexual assault.

\section{SECTION 276}

In 1982, in response to criticism of the treatment of sexual assault victims and the failure of the courts to implement $s .142$ in a manner consistent with Parliament's objectives, new reforms were introduced, among them were s. 246.6 and s. 246.7. The Honourable John Chretien (quoted in L'Heureux-Dube's, J. dissent in Seaboyer at 39) suggested that the purposes of the changes were the "protection of the integrity of the person, the protection of children and special groups, the safeguarding of public decency, and the elimination of sexual discrimination." ${ }^{28}$ The section prohibited the introduction of any evidence, on behalf of the accused, that concerned the sexual activity of the complainant with any one other than the accused, subject to three exceptions. The exceptions were those that Parliament determined to be relevant to the determination of material issues. Section 246.7 prohibited the introduction of evidence of sexual reputation to either challenge or support the credibility of the complainant.

Criminal Code ss. 276 and 277 (formerly ss. 246.6 and 246.7):

276.(1) In proceedings in respect of an offence under section... 271. 272 or 273. no evidence shall be adduced by or on behalf of the accused concerning the sexual activity of the complainant with any person other than the accused unless

(a) it is evidence that rebuts evidence of the complainant's sexual activity or absence thereof that was previously adduced by the prosecution:

(b) it is evidence of specific instances of the complainant's sexual activity tending to establish the identity of the person who had sexual contact with the complainant on the occasion set out in the charge:or

3h. Ibid. at 274-75.

27. Supra. note 16 it 258.

2x. $\quad$ Standing Committec on Justice and Legal Affairs, "Minutes of Proceedings and Evidence," Issue No. 77, (22 April 1982) at 77:29. 
(c) it is evidence of sexual activity that took place on the same occasion as the sexual activity that forms the subject-matter of the charge, where that evidence relates to the consent that the accused alleges he believed was given by the complainant.

(3) No evidence is admissible under subsection (1) unless the judge, provincial court judge or justice, after holding a hearing in which the jury and the members of the public are excluded and in which the complainant is not a compellable witness, is satisfied that the requirements of this section are met.

277. In proceedings in respect of an offence under section... 271, 272 or 273, evidence of sexual reputation, whether general or specific, is not admissible for the purpose of challenging or supporting the credibility of the complainant."

The sections were subject to several constitutional challenges, primarily on the basis that they violated sections 7 and 11 (d) of the Charter:

7. Everyone has the right to life, liberty and security of the person and the right not to be deprived thereof except in accordance with the principles of fundamental justice.

11. Any person charged with an offence has the right

(d) to be presumed innocent until proven guilty according to law in a fair and public hearing by an independent and impartial tribunal.

\section{JUDICIAL INTERPRETATION}

In the following discussion of judicial responses, I will concentrate on $\mathbf{s . 2 7 6}$, as there was general agreement that s. 277 was constitutional. The limited probative value of reputation evidence was generally considered to be outweighed by the prejudicial effect and the likelihood of distracting the trier of fact. The cases dealing with s. 276 can essentially be divided into two categories: those decisions which viewed the loss of judicial discretion to determine relevance as unconstitutional and those which found that the section allowed for the admission of all possibly relevant evidence. In Bird v. Pebbles, ${ }^{31}$ the court found that the limits in the section allowed for reasonable exceptions and permitted the accused to adduce all the reasonably relevant evidence. In $R$. v. Wiseman, ${ }^{31}$ Cusinato D.C.J. found that the section reaffirmed, and in some cases, expanded upon the common law rules by admitting some evidence that might not have been admissible under the common law. In $R$. v. LeGallant, ${ }^{32}$ the B.C. Court of Appeal reversed the trial judge's findings on the basis that the exceptions in the section covered virtually all examples of relevant evidence. Hinkson, J.A. noted that Parliament's intention was not to prevent an accused from making full answer and defence, but to

2\%. R.S.C. 1985, c. C-46.

30. (1984), 4 C.R. (3d) 41 (Man. Q.B.) application to quash on other grounds granted (1984), 27 Man. R. 241.12 C.C.C. (3d) 523 (C.A.).

31. (1985), 22 C.C.C. (3d) 12 (Ont. Dist. Ct.).

3. (1986), 29 C.C.C. (3d) 291, 33 D.L.R. (4th) 444. 54 C.R. 46 (B.C.C.A.) overruling (1985), 47 C.R. (3d) 170 (B.C.S.C.) (hereinafter LeGallant (C.A.) cited to C.C.C]. 
define its own and contemporary society's concept of what is relevant and material in assessing a complainant's rape allegation.

In $R$. v. Brun, ${ }^{33}$ Deschenes, J. found the section to be unconstitutional because it did not allow for the admission of facts that were probative and not prejudicial.

In my view it is not very difficult to imagine circumstances where, by reason of the limitations imposed by s. 246.6. the proffered evidence...does not fall within the narrow exceptions, but nevertheless could not be adduced despite its strong probative value going directly to consent or apprehended consent.

In lact, the proffered evidence in the Coombs and LeGallant cases are in my opinion illustrative of the protective cast around a complainant to exclude evidence of signiliciant probative value. ${ }^{3}$

He discussed Parliament's intent and purpose in passing s. 276,

Parliament has made a value judgement to the effect that the sexual activity of the complainaut with persons other than the accused cannot have any probative force outweighing the prejudicial effect on the issue of consent or apprehended consent. ${ }^{\text {s }}$

and proceeded to find that the purpose was unconstitutional. He further supported his argument by noting that certain evidence that was admitted under s. 142 would not be admissible under s. 276, ignoring the fact that it was the problems created by judicial interpretation of s. 142 that led Parliament to introduce s. 276. The decision reflects the judicial resistance to any attempt to deprive the judiciary of its traditional discretionary role in determining the relevance and admissibility of evidence in particular cases.

The trial decision in $R$. v. LeGallant $t^{36}$ is interesting to note as it was a decision by McLachlin, J. In LeGallant, the trial concerned the statutory sexual assault of a thirteen year old boy by a man in his thirties. The defence wished to adduce evidence of the boy's previous "sexual history." Two years previously, the child had been sexually assaulted and the men involved in that offence had subsequently been convicted. The defence wished to use the evidence to demonstrate that the boy could have been the "aggressor" in the case at trial, and that his previous sexual history demonstrated that he had knowledge of homosexual activity that would make such a contention more likely.

At trial, McLachlin, J. found that s. 276 was unconstitutional on its face because it was a blanket exclusion that preempted the judge's discretionary power to rule on otherwise relevant and admissible evidence. Her Charter analysis began with an examination of the purpose of the section which she found to be constitutional. She held that the effect of the section, however, was to unjustly deprive an accused of an opportunity to adduce this

4. Ibid. at 406 . It is interesting to note that L.'Heureux-Dube, J. in Seaboyer suggests that, in fact, the proffered evidence in Coombs was likely admissible under s. 276. I Hurther, the facts in LeGallam do not justify a finding of probative value far outweighing its prejudicial effect.

35. Ihid. at 406 .

3. Supra. note 32. 
relevant and admissible evidence. In analyzing the section for the purposes of section 1 of the Charter, she balanced the fundamental interest of protecting the rights of the accused from the power of the state with the state's interest in protecting complainants from embarrassment and in encouraging the reporting of crime. The accused's interest in a fair trial and in being able to make full answer and defence is dependent upon a jury or judge reaching a true verdict based on true facts and circumstances. She found that although the interests of the state are valid, they were outweighed by the accused's interest. She notes:

Only for the gravest of reasons. if ever. is it conceivable that these principles should be compromised.

The potential embarrassment of the complainant, however distasteful that may be, is not such a reason. ${ }^{37}$

The result of her decision was to strike down the section and return to s. 142. In the voir dire, on the facts of the case, she found that the probative value of the proffered evidence was outweighed by its prejudicial effect, and it was not admitted.

In $R$. v. Wald, ${ }^{38}$ a similar result was reached; however, Hetherington, J. also suggested guidelines for determining relevance. She found that the purpose of s. 276 was constitutional but suggested that the principles of fundamental justice required that a hearing must be fair to both the Crown and the defence. She found that the effect of the legislation was to offend s. 7 and s. 11(d) of the Charter. To support her finding, she notes two types of evidence that would be relevant and of sufficient value to outweigh the prejudicial effect - (a) evidence that a complainant engaged in sexual activity "bearing very distinctive characteristics or in very distinctive circumstances ${ }^{\mathbf{m 3 9}}$ and (b) evidence of the complainant's sexual activity that would support the accused's honest but mistaken belief in consent. She concluded that the section cannot be justified under $\mathrm{s} .1$ of the Charter and that it was of no force and effect. However unlike McLachlin, J. in LeGallant, she added further that the result was not to return the law to its former state under the common law but, rather, to have evidence of a complainant's sexual activity admitted according to the trial judge's discretion within guidelines of modern understanding of relevance, recommending a model rape shield law proposed by Vivian Berger $^{41}$ as a guide to the kinds of evidence that should be admissible."

A slightly different scenario is developed in $R$. v. Coombs ${ }^{42}$ and $R$. v. Oquataq..$^{13}$ In these cases, the courts found the section to be unconstitutional on the basis that the section would not allow the admission of evidence that was relevant and not prejudicial. This evidence, however, was in fact arguably admissible under the section. ${ }^{+4}$ The facts situations in Oquataq and Coombs are essentially similar in that in both cases the defence

37. Ibid. at 180

Ibid. at 340 .

"Man's Trial. Women's Tribulation: Rape Cases in the Courtroom" (1977) 77 Col. L.R. I.

For a discussion and critique of Hetherington, J.A.'s approach see Sheehy, supra, note 11. (1985), 23 C.C.C. (3d) 356, 49 C.R. (3d) 78, 56 Nifd. and P.E.I.R. 15 (Nfld. S.C.) (hereinafter Combs cited to C.C.C.I.

(1985), 18 C.C.C. (3d) 440 (N.W.T.S.C.) [hereinafter Oquataq cited to C.C.C.].

See page 37. 
wished to adduce evidence to rebut the Crown's evidence regarding injuries allegedly arising as a result of the rape. Oquataq concerned a woman who, after the alleged assault, returned home and had intercourse with a second man. The defence wished to adduce evidence of this to show that the bruising, which allegedly was a result of the rape, was in fact a result of the second encounter.

\section{Re Seaboyer and The Queen; Re Gayme and The Queen. ${ }^{45}$}

\section{A. ONTARIO COURT OF APPEAL}

In Seaboyer, the accused was charged with assault following an encounter with the complainant at his residence. The complainant was a woman whom he had met in a tavern. The facts in Gayme concerned an alleged assault of a fifteen year old girl in the basement of a Toronto school. In both cases, the defence wished to adduce evidence of prior sexual history at the preliminary inquiry. Grange, J.A., for the majority of the Ontario Court of Appeal, held that there was no intention on the part of Parliament to exclude evidence necessary to a defence and that, therefore, the section's purpose did not infringe the Charter. He found that the effect of s. 276 was in the main constitutional. He suggested that the exceptions to the exclusionary rule "encompass...the vast majority of the situations that might give rise to a valid defence." ${ }^{146}$ There may be occasions, however, where the excluded evidence could be relevant to a legitimate defence and the exclusion of that evidence would be contrary to the Charter.

In my view. the evidentiary restriction contained in s. 246.6 is not on its face contrary to any provision of the Charter. IT]here may be occasions - very difficult to define - where that effect may result. But those occasions will be rare and will depend on the circumstances of the case. ${ }^{47}$

He proposes that constitutional exceptions be made pursuant to s. 52(1) of the Charter such that in the particular circumstances of a case, where the effect of the section would be to deprive the accused of his s. 7 and 11(d) rights, the section would be of no force and effect.

\section{SUPREME COURT OF CANADA}

\section{A. RELEVANCE}

While we cannot legally define relevance, and we, of necessity, must therefore leave it to the trial judge's sound exercise of discretion, subject to review, we need to recognise that "common sense and experience," hence relevance, will vary depending upon the judge's culture. gender, background, social origin and age. ${ }^{4 x}$

45. Supra, note 14.

th. Ibid. at 63 .

47. Ibid. at 67.

4*. R.J. Delisle, Evidence: Principles and Problems, 2nd ed. (Toronto: Carswell, 1989) at 10. 
The answer in my opinion lies in gender neutral principles of criminal law which combine to produce the result that evidence will be relevant where, assuming it is true, a reasonable trier of fact could find that the evidence makes one of the competing versions offered by the partics more likely than it would seem in the absence of such evidence."

The issue of relevance appears to be the basis of most of the arguments against rape shield laws. It is argued that the exclusion of relevant and otherwise admissible evidence violates the accused's right to make full answer and defence as required by s. 7 or s. II(d) of the Charter. Relevance, as pointed out by Delisle, is not an exact term. It is described as a process of logical inference informed by common sense and experience. The question of whether something is relevant to an issue may be framed as whether the proof of such a fact is sufficiently connected to the issue that, when proven, it demonstrates that the fact in issue is either more or less likely to be true.

Clearly, relevance is a contextual concept. It does not exist in the abstract but is dependent on the facts in issue. Since it is such a fluid concept, what is relevant to one person, will not necessarily be deemed to be relevant to another. It is a concept that is "particularly vulnerable to the application of private beliefs." ${ }^{.50}$ It is, as Madame Justice L'Heureux-Dube points out, a concept that can frequently be affected by stereotype and myth, and, therefore, determination of relevancy in an area such as sexual assault law can be plagued with prejudice so deeply instilled and universal it is difficult to identify. Frequently courts have stated that something "is clearly relevant," without further analysis, when further analysis could demonstrate that the "clear relevance" is in fact questionable or at least arguable." As pointed out by Shechy:

Even more problematic is the fact that these beliefs are insidious because they are taken for granted and are therefore almost irresistible to the trier of fact who has absorbed our culture. ${ }^{52}$

That the determination of relevancy as clearly a subjective exercise appears to have been rarely disputed. As pointed out by Paciocco:

The fact that relevance is to be assessed as a matter of human experience presents grave problems for the resolution of the controversy concerning evidence of the sexual conduct of the complainants on other occasions... This is because there is, in truth, no homogeneous human experience...People draw conclusions upon a whole panoply of generalizations which others find wrong-headed or even obtuse or offensive..$^{53}$

Given this recognition of the inevitable inclusion of personal experience, belief and understanding in the determination of relevance, it seems surprising that Paciocco argues in favour of relying on what he calls "gender neutral principles." Gender is as much a part of what forms the perception of relevance as belief and experience. He criticises the

See for example Seabover, supra, note 5 at 616. per McLachlin, J., LeGallant, supra, note 33. Seaboyer C.A.. supra. note 14.

Sheehy, supra, note 11 at 166.

Supra. note 12 at 129. 
feminist lobbying that brought about the legislative changes in the Criminal Code, including s. 276, on the basis that it reflected feminist generalizations about how the world operates. He further suggests that the exclusion of sexual history evidence was a question of policy, not relevance, noting that "the invalidation of beliefs, even unattractive beliefs or beliefs which presume an unattractive world, has nothing to do with relevance.".5Given that relevance must depend on someone's perceptions, beliefs, values and experiences, and given that $90 \%$ of the victims of sexual assault are women, surely is it not unreasonable to suggest that the determination of what is relevant be developed according to women's point of view. Although it is appealing to argue for a genderneutral approach, the reality is that the law is a male construct, and what is perceived to be gender-neutral, is in fact premised on the male perception of how women tend to behave. Paciocco (at 130) quotes E.L. Greenspan, a criminal defence lawyer commenting on rape shield legislation. "Indeed, they [feminists] seem unable to conceive of such concepts outside their own terms of reference." ${ }^{.55}$ Indeed, this comment clearly reflects the inability of Paciocco and others to do just that.

The point of departure between the majority and the dissent in Seabover is whether past sexual history can ever be relevant. McLachlin, J. rejects the old common law myths about sexual history being relevant on the basis that an unchaste woman is more likely to consent and more likely to lie but contends that there will be occasions when past sexual history will be relevant, and that not all of those occasions are covered by the exceptions in s. 276. She points to two fatal flaws in the section, as identified by commentators. The first is that the section excludes evidence of prior sexual history, no matter the purpose for which it was tendered. She suggests that while introduction of the evidence for the sole purpose of inferring consent or impeaching credibility would be illegitimate, there are examples of valid purposes and where the proffered evidence would be clearly relevant and helpful. The second criticism of the section is that it attempts to "pigeon-hole" types of evidence, to predict relevancy based on categories. McLachlin, J. quotes Sopinka, J. as stating that the test for relevancy "must be sufficiently flexible to accommodate the varying circumstances in which it must be applied." ${ }^{\text {"56 }}$ She comments that the blanket exclusion contemplated by the section gives the trial judge no room in which to determine if the evidence falls within a valid purpose or to determine relevancy on the facts of the individual case.

L'Heureux-Dube, J.'s approach, in dissent, is that none of the evidence that is excluded is likely to be relevant, but that if it is, it is properly excluded because of "its extremely prejudicial effect on the trial of the legal issues.". ${ }^{57}$ She notes that "a determination that something is relevant does not answer the further question of whether, regardless of its relevance, there exists some rulc or policy consideration that nevertheless mandates exclusion of the proffered evidence." 58

Ihid. at 130.

E.L. Greenspan \& G. Jonas, Greenspan: The Case for the Defence (Toronto: McMillan of Canada. 1987) at 229.

Seaboyer, supra, note 5 at 619.

Seaboyer, supra, note 5 at 691.

Ibid. at 691 . 


\section{B. PREJUDICE}

The ability of the trial judge to exclude relevant evidence on policy or other grounds is an important aspect of evidence law. Canadian law, as defined in Morris v. The Queen, ${ }^{59}$ holds that only evidence which is logically probative is to be admitted and that that evidence may be excluded on the basis of a variety of evidentiary rules and policy grounds. In general, the balancing test will involve a determination of whether the probative value of the evidence outweighs its prejudicial effect. Prejudice is not to be determined on the basis of some detrimental effect upon an individual but upon its potentially disruptive influence upon the trial process itself. The rationale underlying the exclusion of prejudicial, though relevant evidence, is outlined by McCormick in McCormick's Handbook of the Law' of Evidence. ${ }^{61)}$ The first reason for exclusion is the danger that such evidence may unduly arouse the emotions of the trier of fact, whether emotions of prejudice, hostility or sympathy. The second reason is to avoid the creation of a side issue that may unduly distract the trier of fact. The time element is another factor underlying the rule. It was intended to ensure that an inordinate amount of time was not taken up in offering and responding to the evidence of only limited value. The fourth reason was to prevent unfair surprise.

While the general rule is against admitting evidence whose prejudicial effect outweighs its probative value, in the area of criminal law, where the liberty of the accused is at stake, the tendency of the courts has been to protect the individual defendant from the power of the state and to limit exclusion of prejudicial evidence to that evidence sought to be adduced by the state. This reluctance, notes McLachlin, J., is "founded in the fundamental tenet of our judicial system that an innocent person must not be convicted." trial judge in areas such as character and similar fact evidence, the rules have hardened in order to protect the accused. ${ }^{62}$ However, for the purposes of witness impeachment, there appears to be a remaining requirement of discretion in these areas. Character evidence that would probably not be admissible against a criminal defendant could be admissible in regards to credibility of a witness. The question remains one of balancing:

How far in any particular situation does the danger of unfair prejudice against the witness and the party calling him from this type of impeachment outweigh the probable value of light shed on credibility $?^{63}$

McLachlin, J.'s answer is that "the prejudice must substantially outweigh the value of the evidence before a judge can exclude evidence relevant to a defence allowed by law." The argument put forward by the majority is that s. 276 deprives the trial judge of the discretion to perform that balancing, and that he is in the best position to do so on the basis of the individual facts of each case.

(w). 2nd ed., (St. Paul Minn.: West Publishing Co., 1972) at 439-40.

ol. Seaboyer, stupra, nole 5 at 611.

62. Supra, note 65 at 440 .

b. Ihid. at 81 .

os. Seabover, supra, note 5 at 611 [emphasis added]. 
However, L'Heureux-Dube, J. analyzes the problem of prejudice from the perspective firstly of the prejudicial effect on the trial process itself, rather than from the perspective of prejudice to the accused. The root of the rule regarding prejudice is the protection of the trial process from evidence that distorts, rather than enhances, the search for truth. She argues that sexual history evidence invariably triggers myth and stereotype and shifts the focus of the trial and of the trier of fact away from the true issues of the case, and that, therefore, exclusion of that evidence is a valid, and probably, the only means of dealing with its prejudicial effect. She again quotes the Catton study: "Any information at all implying that the victim had a prior sex history had the effect of reducing the perceived guilt of the accused regardless of whether the information was verified," 1.5 and concludes that it is indisputable that sexual history evidence has a profound prejudicial effect, arguably sufficient to outweigh the probative value.

\section{CONSTITUTIONAL ISSUES}

McLachlin, J. concludes that s. 276 of the Criminal Code infringes the rights in ss. 7 and II(d) of the Charter. While accepting that the purpose of abolishing "outmoded, sexist-based use of sexual conduct evidence" ${ }^{166}$ is constitutional, she holds that the effect is too broad. She suggests that the risk of an innocent person being convicted because he is unable to adduce the necessary and relevant evidence to prove his innocence, is not justified. She argues that evidence which could, absent the section, be validly led, and which does not rely on sexist and illegitimate inferences, is excluded depriving the accused of an opportunity to present full answer and defence. The types of evidence which she suggests could be improperly and unjustly excluded include evidence that supports a mistaken belief in consent, similar fact evidence and evidence that goes to bias or motive to fabricate. The absolute exclusion of the evidence, without any means for assessing whether its probative value outweighs its prejudicial effect is contrary to the principles of fundamental justice, as the exclusion can unjustly deprive the accused of his liberty.

In analyzing whether s. 276 is justified in a free and democratic society, despite its infringement of the Charter rights, McLachlin, J. accepts that the legislation is addressed to a pressing and substantial objective. In the proportionality analysis of s. 1, she finds that there is a rational connection between the legislation and its objective. She holds, though, that the legislation does not impair the rights as little as possible. She notes that the exceptions that are already in the Code indicate Parliament's attempt at a measured approach, but she suggests that the approach was not restrained enough. The exclusion of some relevant evidence for its possible prejudicial effect, but not others, despite the lact that they too might have a prejudicial effect, indicates, she says, that the section is overbroad. The third element in the s. 1 analysis is the balancing of the importance of the objective with the injurious effect of the legislation. She defines the objectives of the legislation as eradicating erroneous inferences that could be derived from sexual history evidence, promoting fair trials, encouraging the reporting of crime, and minimizing the

to. Seabover, supra, note 5 at 625 . 
invasion of a complainant's privacy. "In this way the personal security of women and their right to equal benefit and protection of the law are enhanced." ${ }^{67}$ The injurious effect of the legislation is to rule out probative defence evidence that is not outweighed by the prejudice it may cause. This, she holds, clearly is an inappropriate balancing. "The line must be drawn short of the point where it results in an unfair trial and the possible conviction of an innocent person." ${ }^{\text {"ti }}$

Essentially the basis of the majority's decision is that the absence of judicial discretion to determine admissibility is unconstitutional. The $\mathbf{s .} 1$ analysis is very brief, and does not address any of the voluminous evidence raised in the dissent. The analysis seems to take place in a vacuum, with no contextual basis in the real world. The evidence of unreported rape, of high unfounded rates, and of low conviction rates are not addressed. Social science evidence that indicates how juries respond to evidence of the complainant's sexual history is not discussed. Neither does she address the problems of bias in the judiciary, the cause, at least in part, for the enactment of the legislation. The fact that relevance, prejudice and probativeness are very subjective concepts is not adverted to, although the inclusion of guidelines for the types of evidence that could be admitted answers the problem somewhat. ${ }^{\text {"1) }}$ Anne Stalker comments that "Too much discretion leads to inequities of application. Therefore, if a discretion is to be left, its parameters must be carefully defined. ${ }^{.71}$ It remains to be seen how carefully defined these parameters actually are.

In the dissenting judgement, L'Heureux-Dube, J. responds to many of the points raised in the majority decision. She suggests that the types of evidence that are said to be relevant are really based on myth and stereotype and have no place in the trial process or in the search for truth. She discusses the rationales for excluding evidence, such as protecting values, avoiding inherent unreliability, and ensuring fairness. She argues that s. 276 is, in fact, necessary to the promotion of fairness and the principles of fundamental justice. She notes that ss. 7 and 11 (d) not only protect the interests of the accused but other interests in society as well. McLachlin, J. adverts to the existence of these other interests at page 40, but she never pursues them. L'Heureux-Dube, J. goes on to quote La Forest, J. from Corbett:

"fairness" implies, and in my view demands, consideration also of the interests of the state as representing the public. Likewise the principles of fundamental justice operate to protect the integrity of the system itself, recognizing the legitimate imterests not only of the accused but also of the accuser."

She suggests that the small callegory of relevant sexual history evidence which is excluded by s. 276 is excluded for a number of valid reasons, and that those reasons outweigh the argument that the accused's rights are thereby violated because he is unable to adduce all

Ibid. at 627.

Ibid. at 627.

See "Principles of Valid Rape Shielding Provisions" infia.

"LeGallant: Law Relorm and the Charrer" (1986) 54 C.R. 61 at 67.

R. v. Corbett (1984), 17 C.C.C. (3d) 129, 43 C.R. (3d) 193, 13 C.R.R. 250 (B.C.C.A.) at 745; quoted in Seaboyer. supra. note 5 at 698. 
relevant evidence. There is no right in the accused to adduce evidence which distorts the fact finding process. Therefore, s. 276 does not exclude any evidence that would not be properly excluded at common law and under the Charter.

L'Heureux-Dube, J. also undertook to justify the legislation under s. 1 of the Charter. She finds that the purpose of the legislation was to eliminate sexual discrimination in the trials of sexual offenses by excluding irrelevant and prejudicial sexual history evidence. Parliament's goals included protection of the integrity of the person, safeguarding public decency, and encouraging the reporting of crime. While she found these goals sufficiently important in themselves, she also states that the goals of the Charter also justify the legislation: sections such as ss. 15 and 28 mandate the legitimacy of eliminating sexual discrimination. She argues further that the Code provision is rationally connected to the objective: it impairs the right as little as possible. She notes that this is Parliament's second attempt at combatting the problem and states:

\footnotetext{
Parliament exhibited a marked, and justifiedly so. distrust of the courts to promote and achieve a nondiscriminatory application of the law in this area. In view of the history of government attempts, the harm done when discretion is posited in trial judges and the demonstrated inability of the judiciary to change its discriminatory ways, Parliament was justified in so choosing. My attempt to illustrate the tenacity of these discriminatory beliefs and their acceptance at all levels of socicty clearly demonstrates that discretion in judges is antithetical to the goals of Parliament. ${ }^{72}$
}

She argues further that the deleterious effects of s. 276 do not outweigh the importance of the objective. She suggests that there are still areas where relevant sexual history is admissible, and that the exclusions are of largely irrelevant and prejudicial evidence. Thus, she concludes that there is no serious effect upon an accused's rights. She states, "even assuming that s. 276 is unconstitutional in its effect, it is easily justified under $s$. 1. In my view, once the constitutional questions are viewed within their larger context, the conclusions reached in these decisions are absolutely uncontentious. ${ }^{.73}$

The interesting thing to note when comparing the two judgments is that neither seems able to respond to the issues raised by the other. Although L'Heureux-Dube, J. appears to address each of the types of supposedly admissible evidence excluded under the section, as defined in the majority judgement, she never comes to grips with the arguments raised. Similarly, she never deals with the point raised by McLachlin, J. that the result of the section may be the conviction of an innocent person. The majority judgement never reaches beyond the point of arguing that the accused rights are infringed to discuss the interrelationship of society's interests in a trial process that is balanced. Nor does the judgement address Charter rights within the context of society as a whole so as to discuss whether society's interest in equality and in security of the person relate not only to the accused, but to society in general. I suggest that this apparent incongruency is a function of perspective. When the issue is viewed from a contextual point of view, including consideration of what actually happens in "the real world." the 
situation seems clear. Women's sexual history is not the basis on which they themselves make choices about sex, rape is a threat that hangs over every female, myth and stereotype exist at all levels of society, including the judiciary, and the reality is that sexual conduct with someone other than the attacker is not relevant. Viewed from the context of legal theory, it seems equally clear that the protection of the accused from the unfettered power of the state is an essential function of law, that no person who is innocent should ever be convicted, that evidence which has a logical and probative connection to a fact in issue should be admitted, and that rights of an accused to present as much of that evidence as may prove his innocence is essential to his Charter rights. Given the shifts in perspective it seems unlikely that the two sides can be reconciled, short of major changes in the law of sexual assault.

\section{PRINCIPLES OF VALID RAPE SHIELDING PROVISIONS}

In the majority judgement, McLachlin, J. suggests that the invalidity of s. 276 does not result in an automatic return to the old common law principles. She sets out judicial guidelines that the court would consider to be constitutional. The principles lay out a general prohibition against the admission of previous consensual sexual conduct for the purposes of supporting inferences regarding consent or credibility and then describe criteria where evidence may be admissible for other purposes. These exceptions are specifically not closed and are illustrations of likely examples. They include evidence tending to prove that someone other than the accused caused the physical consequences of the alleged rape in question, evidence tending to prove motive to fabricate or bias, evidence supporting honest but mistaken belief in consent, similar act evidence, and evidence tending to rebut prosecution evidence of the complainant's sexual conduct. The first, third and fifth examples are similar to, or the same as, the exceptions laid out in s. 276. Her summary is as follows:

I. On a trial for a sexual offence, evidence that the complainant has engaged in consensual sexual conduct on other occasions (including past sexual conduct with the accused) is not admissible solely to support the inference that the complainant is by reason of such conduct:

(a) more likely to have consented to the sexual conduct at issue in the trial;

(b) less worthy of belief as a witness.

2. Evidence of consensual sexual conduct on the part of the complainant may be admissible for purposes other than an inference relating to the consent or credibility of the complainant where it possesses probative value on an issue in the trial and where that probative value is not substantially outweighed by the danger of unfair prejudice flowing from the evidence.

By way of illustration only, and not by way of limitation, the following are examples of admissible evidence:

(A) Evidence of specific instances of sexual conduct tending to prove that a person other than the accused caused the physical consequences of the rape alleged by the prosecution; 
(B) Evidence of sexual conduct tending to prove bias or motive to fabricate on the part of the complainant;

(C) Evidence of prior sexual conduct, known to the accused at the time of the act charged, tending to prove that the accused believed that the complainant was consenting to the act charged. (Without laying down absolute rules, normally one would expect some proximity in time between the conduct that is alleged to have given rise to an honest belief and the conduct charged);

(D) Evidence of prior sexual conduct which meets the requirements for the reception of similar fact evidence, bearing in mind that such evidence cannot be used illegitimately merely to show that the complainant consented or is an unreliable witness.

(E) Evidence tending to rebut proof introduced by the prosecution regarding the complainant's sexual conduct;

3. Before evidence of consensual sexual conduct on the pan of a victim is received, it must be established on a voir dire (which may be held in camera) by affidavit or the testimony of the accused or third parties, that the proposed use of the evidence of other sexual conduct is legitimate.

4. Where evidence that the complainant has engaged in sexual conduct on other occasions is admitted on a jury trial, the judge should warn the jury against inferring from the evidence of the conduct itself, either that the complainant might have consented to the act alleged, or that the complainant is less worthy of credit. 7

These principles raise several questions. They apply to consensual sexual conduct; however, it is not clear as to whether previous non-consensual conduct would be admissible. While it seems unlikely that non-consensual conduct would be relevant, it was the non-consensual conduct of the complainant in LeGallamt ${ }^{75}$ that McLachlin, J., at trial, considered to have some probative value. The examples are also broader than $\mathrm{s}$. 276 in that they would exclude evidence of past sexual conduct with the complainant where s. 276 would allow evidence (presumably evidence determined to be relevant) of past sexual conduct with the accused. The exclusion would not be a blanket exclusion but, rather, would exclude the evidence if it went solely to support inferences that a woman's sexual history made it more likely that she would lie or consent. In other words, the evidence would be admissible if it were relevant to other material issues of the offence, or to issues of consent or credibility that did not rely on myth and stereotype. The material issues, drawn from the code section, would include proof of identity, the absence of consent, the application of force, and the requisite mens rea, which would include the defence of honest but mistaken belief in consent.

The proposed examples of the types of evidence that should be admitted address many of the problems identified in the previous cases. The examples cover areas where a blanket exclusion could result in limiting an accused's ability to present a defence. 
However, they do not address the problem of the distortion of the trial process raised by L'Heureux-Dube, $\mathbf{J}$. in her dissenting judgement, nor the concerns of Parliament that motivated it to limit judicial discretion in order to protect both the justice system and the complainant. The primary purpose of such evidence in the past has been to rely on myth and stereotype to establish credibility or consent; the process of declaring the use of such evidence as illegitimate for these purposes is unlikely to alleviate the prejudicial effect the evidence has on the trier of fact in regards to both consent and credibility. ${ }^{76}$

The third clause in the guidelines is similar to the code provision. They both call for a voir dire to determine the legitimacy of the evidence, and both direct that the complainant is not compellable. The suggested provision, however, does not require the voir dire to be held in camera, an element that limits the protection of privacy afforded to the complainant. It is interesting to note that even the muchly criticized s. 142 required that the voir dire be held in camera. The fourth clause mandates a warning to a jury that the evidence of sexual history is not to be used to infer that consent is more likely or that the complainant is more likely to lie. In light of the evidence discussed by Madame Justice L'Heureux-Dube (at pages 23-27 of the dissent) the effectiveness of such a warning is clearly arguable.

\section{A. REBUTTAL - EXAMPLE E}

This example is virtually identical to s. 276 (1)(a).

\section{B. IDENTITY - EXAMPLE A}

This is arguably the same as s. 276(1)(b). Both sections allow for the admission of specific instances of sexual conduct that would tend to prove the identity of the person who caused the physical consequences of the rape as alleged by the prosecution. In this sense, the two code sections, s. 276(1)(a) and 276(1)(b) (examples A and E) overlap somewhat. They both provide a means for rebutting evidence introduced by the prosecution and are thus always relevant. The distinguishing element may be one of time. The code section refers to "evidence of specific instances of the complainant's sexual activity tending to establish the identity of the person who had sexual contact with the complainant on the occasion set out in the charge." If this is interpreted to mean that only evidence of sexual activity at the time of the alleged offence is admissible, it may be more restrictive than the proposed example. However, it is more logical to suggest that the phrase "on the occasion set out in the charge" is intended to describe, not the time frame of the specific instances of sexual activity, but to indicate the appropriate time for identification purposes. In other words, if the prosecution has alleged that as a result of the alleged rape, the complainant has suffered physical injury, it is open to the defence to present evidence of some other sexual act that caused the injuries. The facts in Coombs ${ }^{77}$ and Oquataq ${ }^{78}$ are of this general pattern, and the courts in those cases found the evidence to be inadmissible under the section. However, L'Heureux-Dube, J., in 
Seaboyer indicates that this evidence clearly should have been admissible and that it was unnecessary to find the section unconstitutional. ${ }^{79}$

The only proviso in the section is that the evidence must demonstrate, or at least point to, the identity of the party who caused the physical consequences, whereas the suggested example is broader. It states only that the evidence must tend to prove that the physical consequences were caused by someone other than the accused. This is essentially only a semantic difference, because the evidence of a specific instance of sexual activity that demonstrates that the effects were not caused by the accused will, by implication, identify some other party. The process of proving that it was not the accused effectually proves that someone else caused those effects, and this would seem to fulfil the requirement of "tending to establish the identity of the person who had sexual contact with the complainant."

\section{BIAS AND MOTIVE TO FABRICATE - EXAMPLE B}

Evidence that goes to bias and motive to fabricate is by its nature evidence that goes to credibility. The whole point of such evidence is to cast doubt on the testimony of the witness. Such evidence will have little or no bearing on such material issues as the presence or absence of consent, on identity, or on the use of force. McLachlin, J.'s inclusion of this example suggests that it is not to be considered for the illegitimate purpose of inferring lack of credibility solely on the basis of the existence of some past sexual history. The legitimate purpose of such evidence would be to show that because of some particular facet of the complainant's past sexual history, the complainant had some motive to fabricate or some bias. Generally this typical type of witness impeachment evidence will not involve the evidence of sexual conduct with someone other than the accused. More often than not the relevant sexual history will be that of the relationship with the accused.

The example cited by McLachlin, J. is based on an American case State v. Jalo, ${ }^{80}$ where a father accused of sexual acts with his young daughter wanted to raise evidence to demonstrate bias and motive to fabricate. The daughter was said to have had an incestuous relationship with her brother, and when her father stopped the relationship, she concocted the charges against him for revenge. This example still speaks to the myths identified by L'Heureux-Dube, J. The stereotype of vengeful and angry females alleging rape to get even, or of women who regret a sexual encounter and then cry rape, are creations of myth and society's preoccupation with the unreliable and untrustworthy woman. "(T)he relevance springs from an archetype of our pornographic imagination of the sensually voracious, treacherous, malicious, sexual female child. "81 L'Heureux-Dube, J. suggests that:

xı. A. Acorn, "R. v. Seabover: Pornographic Imagination and the Springs of Relevance," [unpublished case comment]. 
...much of this evidence depends for its relevance on certain stereotypical visions of women, that they lie about sexual assault, and that women who allege sexual assault often do so in order to get back in the good graces of those who may have her sexual conduct under scrutiny. ${ }^{22}$

Sheehy notes that the rate of false reporting of sexual assault is no higher than for any other offence, and adds that "Given the very high rate of non-reporting of sexual assault by victims themselves, and the rate at which police and Crown attorneys refuse to investigate and prosecute this offence, the obsession with fabrication seems entirely misconceived." ${ }^{83}$ The danger of allowing this kind of evidence is that, in a contest between two versions of a story, evidence going to bias or motive to fabricate will be bolstered by the underlying and pervasive stereotypes of women who lie, fantasize and make up stories. While it should be open to the defence to adduce evidence that demonstrates a motive for fabrication, to base that motive on a sexual relationship with someone other than the accused, as in Jalo, is to again rely on outdated and discredited ideas about how women act and behave.

\section{HONEST BUT MISTAKEN BELIEF - EXAMPLE C}

Honest but mistaken belief in consent is a defence going to the mens rea of assault offenses. The requirement in the offence is that to commit assault one must intentionally apply force without the consent of the other party. Pappajohn v. The Queen ${ }^{\text {st }}$ laid out the basis for the defence, including the fact that the belief need not be reasonable, only honest. The judgement held that the defence could only be put before a jury if the judge determined that there was sufficient evidence adduced at trial to give "an air of reality" to the defence. After the decision in Pappajohn, the Criminal Code was amended by the addition of subsection 4 to $\mathrm{s}$. 244, now s. 265. The section directs that the judge should direct the jury to "consider the presence or absence of reasonable grounds for the belief." In Laybourn, Bulmer, and Illingworth v. The Queen, ${ }^{85}$ McIntyre, J., for the majority, held that the amendment did not change the law as applied in Pappajohn; it simply restated what Dickson, J. stated in Pappajohn:

\footnotetext{
...although reasonable grounds is not a precondition to the availability of the plea of honest belief in consent, those grounds determine the weight to be given the defence. The reasonableness, or otherwise. of the accused's belief is only evidence for, or against, the view that the belief was actually held and the intent was therefore, lacking. ${ }^{\mathrm{xt}}$
}

Dickson, J. based his comments on his faith in the jury system and in the juries themselves.

Silura. note 5 at 690.

x. Supra. note 11 at 167-68 (footnotes not included).

x. $\quad$ (1980), 52 C.C.C. (2d) 481, III D.L.R. (3d), [1980] 2 S.C.R. 120, 14 C.R. (3d) 243 [hereinafter Pappajolin cited to S.C.R.].

xs. (1987). 33 C.C.C.(3d) 385.

s. Supra, note 84 at 155 . 
The proposal outlined by McLachlin, J. seeks to expand the parameters of what was considered to be admissible evidence for the purposes of the honest but mistaken belief defence outlined in s. 276(1)(c). The code section allows only for the admission of evidence of sexual activity that took place on the same occasion as the subject matter of the charge, but the principal enunciated in Example $\mathrm{C}$ does not limit the time frame of when the sexual activity took place. However, the example does suggest that there should be some proximity in time between the conduct alleged to have created the belief and the conduct charged. McLachlin suggests that "the basis of the accused's honest belief in the complainant's consent may be several acts performed by the complainant at some other time or place." ${ }^{187}$ Paciocco argues that "If the accused's knowledge of such acts can induce a belief when they occur on the same occasion, why not when they occur the day before or at some earlier point in time?"*\$

As L'Heureux-Dube, J. points out, "...consent is to a person and not to a circumstance." ${ }^{81}$ She contends that the evidence that is excluded does not satisfy "the air of reality" test. What she really is arguing, however, is that evidence of past sexual conduct does not form the basis for a reasomable mistaken belief in consent. The law in Pappajolm and subsequently in Illingworth confirmed that the belief need not be reasonable. Given this analysis, it would be inconsistent to allow a defence and then refuse the accused the opportunity to use it effectively. The argument must be one that opposes the honest but mistaken belief defence itself.

It is inconsistent and irrational to declare that certain types of evidence cannot be used by the courts to make illegitimate inferences about consent, and then allow individuals to make those same inferences to justify their altack. Nothing more clearly illustrates the problem with this defence than the fact that society, Parliament and the courts have agreed that reliance on sexual stereotypes is not a valid means of ascertaining consent for the purposes of adducing evidence. Further, they have noted and considered that the admission of evidence based on stereotype is embarrassing and humiliating in itself. At the same time, the defence of mistaken belief sanctions the use of these stereotypes by an accused to justify an attack that violates a woman's integrity far more than any questions on a witness stand.

Among recent criticism of the defence is an article by Sakthi Murthy. ${ }^{{ }^{10}}$ Murthy argues that there is a need to change the law's approach to sexual assault. She suggests that there are two possible models of sexuality. Drawing from the work of Lois Pineau, she describes these as the contractual model and the communicative model. The contractual model is the model in use today to deal with sexual assault and the defence of mistake.

Under this model, a woman's sexually provocative behaviour creates an implied contract where she is required to fulfil her part of the bargain by submitting to supposedly insistent male sexual needs that her 
own conduct created... A contractual analysis leads to the conclusion that a woman who is sexual with many men creates the expectation that she will fulfil male sexual needs generated by the knowledge of her sexual encounters."

This model is clearly based on the stereotypes and myths that the rape shield laws are endeavouring to eradicate. The communicative model involves an obligation on the part of the man to ensure there is consent. In that case, a valid mistake would have to be based, not on his perception of her past sexual encounters, but on her communication of consent. Evidence of past sexual experience could conceivably be relevant to a defence of mistake if it related to the way the complainant previously indicated her consent.

The positive obligation to obtain consent is also discussed by Lucinda Vandervort." She suggests that the mistaken belief in consent defence is actually a mistake of law which provides no defence. She argues that the definition of consent for the purposes of the law has become infused with societal myths of what consent is. Unless the presence of threats, force, fear, or the exercise of authority are proven, the determination of whether there was consent rests on the trier of fact's interpretation of the complainant's verbal and non-verbal behaviour. The interpretation is likely to be informed by stereotype, myth and experience and may well not reflect the reality of whether there actually was consent. When the question of mistaken belief is factored into the analysis, the results are likely to be even more subjective. She argues that this subjective interpretation of consent is not consonant with the legal definition of consent in other areas of the law and concludes that the reliance on this construction of consent to prove mistaken belief denies women their personal autonomy and individual liberty.

\section{E. SIMILAR ACT EVIDENCE - EXAMPLE D}

The similar act rules were developed to deal with evidence of an accused's actions that were similar to the actions of which he was accused. Generally the rules held that evidence of similar acts could not be used solely to infer that having done something once, he is more likely to do it again. This is said to be a propensity argument and it is inadmissible against a defendant. To be admissible against a defendant in a criminal case, there must be something more. Some commentators have suggested that the something more must be unique or bizarre, ${ }^{93}$ while others contend that there is no such requirement. ${ }^{94}$ Similar act evidence is admissible only if its probative value outweighs its prejudicial effect and is generally admissible to prove intent, a system, a plan, to show malice, to rebut the defenses of mistake or accident or to prove identity. ${ }^{95}$

\footnotetext{
91. Ibid. at 566.

92. "Mistake of Law and Sexual Assault: Consent and Mens Rea" (1987) 2 C.J. Women and the Law 233.

91. T.B. Dawson, "Sexual Assault Law and Past Sexual Conduct: The Construction of Relevance" (1988) 2 C.J. of Women and the Law 310 at 324.

9. Paciocco, supra, note 12 at 126 note 31 .

\%s. Dawson, supra, note 84 at 324.
} 
McLachlin, J. suggests that the complainant's patterns of conduct, similar to the conduct considered in similar fact evidence, may be relevant to a defence. In $R$. v. Scopaletti, Martin, J. suggested:

[T]he admission of similar fact evidence against an accused is exceptional, being allowed only if it has substantial probative value on some issue, otherwise than as proof of propensity...No such policy rule operates to exclude evidence of propensity with respect to a person other than the accused where that person's propensity to act in a particular way is relevant to an issue in the case."

The suggestion in Scopaletti was that the violent actions of the accused in the past were relevant to the accused's defence of self-defence. It seems illogical to consider the violent acts of a murder victim to be analogous to the volitional sexual conduct of a rape complainant. In the self-defence situation, the defence is trying to establish that there were reasonable grounds for the defendant to fear for his life. The use of the pattern evidence to infer the likelihood of consent or to impeach credibility is an entirely different matter.

The examples used to justify the admission of similar fact evidence against a complainant, again rely on what Sheehy has called "our pornographic imaginations." Scenarios like the extortionate prostitute, the promiscuous and indiscriminate slut at a bar, and the woman who liked rough sex with five men on another occasion, all rely on stereotype and myth. They deny women's autonomy, they imply that consent is based on such factors as location or circumstance, and they objectify and depersonalize women and women's sexual experience. Whether the previous experience was distinctive or bizarre, or simply similar as picking up someone every Saturday night, the use of this evidence to support an inference of consent bears no relationship to how real women act, behave or react. It seems as least as consistent to suggest that the woman who has indiscriminately had sex with many men, and who now alleges rape, is more likely to be telling the truth because she did not allege it on the other occasions. In this light, L'Heureux-Dube suggests that:

Such arguments depend for their vitality on the notion that women consent to sex based upon such extraneous considerations as the location of the act, the race, age or profession of the alleged assaulter, and for consideration of the nature of the sexual act engaged in. ${ }^{97}$

Similar fact evidence often appears to be evidence of habit. Described by McCormick, habit is:

...the person's regular practice of meeting a particular kind of situation with a specific type of conduct. such as the habit of going down a particular stairway two stairs at a time, or of giving the hand signal for a left tum, or of alighting from railway cars while they are moving. The doing of the habitual may become automatic."

(1981), 34 O.R. 524 at 536, 63 C.C.C. (2d) 481 (C.A.)|hereinafter Scopaletti cited to O.R.|, [emphasis added]. 
As L'Heureux-Dube, J. points out, there can be no analogy between volitional sexual conduct and something that can be described as automatic.

The issue of whether prejudice to the accused is analogous to prejudice to the complainant has been raised in relation to similar fact evidence. Paciocco argues that:

\footnotetext{
While a sexual assault complainant may be embarrassed, even humiliated, by the evidence, and while it could cause wrong-minded triers-of-fact to draw inappropriate or even outrageous conclusions about her and about the case, the fact is that she is not being "prejudged" in any way that is in derogation of the presumption of innocence, which, of course applies to the accused alone.(x)
}

This position is not consistent with the general theory of how prejudice relates to probativeness. While it is true that the rules have evolved to protect the accused from the power of the state, and to ensure a presumption of innocence, there is a valid interest in protecting the judicial system from abuse and distortion. McLachlin, J. bases her conclusions on the overbreadth of s. 276 on the requirement of the trial judge to balance the prejudicial effect with the probative value. ${ }^{1(1)}$ This implies that there is room for relevant evidence sought to be adduced by the defence to be excluded because of potential prejudice to the Crown's case. Noting the societal interest in fair trials and the integrity of the trial process, L'Heureux-Dube comments that "an unfettered right in the accused to adduce all relevant evidence, seriously misconstrues the phrase "principles of fundamental justice.'"101

\section{ALTERNATIVES}

There are several possible alternatives to the guidelines set out above. The first, as suggested by Grange, J.A. in Seaboyer, ${ }^{102}$ is the use of the constitutional exemption. McLachlin, J. rejects this approach as obscuring the will of the legislature while still placing the power of discretion in the hands of the trial judge based on common law notions of relevancy. Also it would place a reverse onus on an accused to demonstrate the extent of the unconstitutionality. Other problems with a constitutional exemption include problems of uncertainty. One would never know when the evidence would be admissible: this would deter one of the purposes of the legislation - encouraging reporting of crime. While it could be argued that the trial judge's discretion would be more likely to be exercised in a cautious manner befitting the constitutional nature of the question, it still would not address Parliament's concern about judicial discretion.

A second approach could be to pursue civil action. ${ }^{103}$ This approach is one that has been suggested in terms of fighting the sexual discrimination engendered by pornography. The advantage to this approach would be that it would emphasize that the complainant

w.

(In).

101.

III.

103.

Supra. note 12 at 127.

Supra, note 5 at 620.

Ibid. at 700.

Supra, note 50.

K. Rittich suggested this as a possible approach to avoiding the bonest but mistaken belief in consent defence. 
was more than a witness. She becomes a party to the action with a clearly defined interest in the proceeding. However, at the same time, it relegates another "women's issue" to the realm of private law, negating any public interest in ending the epidemic of violence against women. The burden of proof would still rest on the party alleging the assault, but it is a burden on the balance of probabilities, not beyond a reasonable doubt. Further, there is no requirement to prove mens rea; therefore, the defence could not raise the defence of honest but mistaken belief in consent. Lack of consent would still have to be proven, and because there are no restrictions on witness impeachment evidence in a civil case beyond the common law rules, evidence of previous sexual history might still be adduced. Given that the proceedings are not criminal and that the defendant does not face imprisonment, the balancing of probative value and prejudicial effect might be more evenly evaluated between the partics. However, the existence of the inherent myths and prejudices, discussed infra, suggests that this balance will give little protection.

\section{A. BILL C-49}

Other alternatives include making legislative changes. The government's response to the Supreme Court decision in Seaboyer has been to introduce Bill C-49 An Act to Amend the Criminal Code (Sexual Assault). ${ }^{114}$ The proposed legislation adds a section that defines consent (s. 273.1), defines where a belief in consent will not provide a defence (s. 273.2), and proposes a new formulation of the rape shield provision, (ss. 276, 276.1, 276.2, 276.3). Prior to the introduction of the bill, groups who had met with the Minister of Justice, Kim Campbell, had suggested that a definition of consent would "at a minimum ... define consent as a woman using overt words or actions, which to a reasonable outside observer, would unequivocally communicate voluntary agreement to sexual relations." 115 It was suggested that by defining consent, questioning about a woman's past sexual history would become irrelevant. The proposed section does not have an objective test, but it does attempt to address the problems associated with defining consent by including a non-limiting clause which describes what consent is not.

The drafting of the definition had to be careful and concise. It could not be purely a verbal consent, as that would ignore reality. By defining examples of what does not constitute consent, the drafters were able to exclude certain kinds of behaviours that would not be considered to constitute consent. The problems with the definition lie in the inherent problem of defining something which can be expressed in a million different ways. Turning the definition around so that the definition is in the negative ${ }^{11 \% 6}$ does not add much certainty. It does not address the issue of whether mere acquiesence is sufficient to constitute consent by conduct, or what conduct would be sufficient to

3d Sess., 34th Parl., 1991 (given first reading Dec. 12, 1991). This paper was originally written prior to the introduction of the bill. and a thorough analysis of the contents of the bill is not within the scope of this paper. However I will offer a brief discussion of the bill in relation to the areas addressed in the paper.

1105. Edmomom Journal (22 November 1991) at A.3.

116. For example: s.273.1(2) No consent is obtained. for the purposes of sections 271,272, and 273. where (d) the complainamt expresses by words or conduct. a lack of agreement to engage in the activity. 
constitute a lack of agreement to engage in the activity. The risk of returning to a reliance on the stereotype of women as passive and submissive, or to a requirement of proving resistance, must be kept in mind. Murthy comments:

This is not to say that nonverbal consent is never adequate. When a woman says she does not want to have sex, however, her words should be respected, regardless of the nonverbal signals a man may sense. This is consistent with the law of consent in other situations. For instance, if a panhandler asks for money and is refused, he or she cannot then justify robbery on the grounds of a mistaken belief based on nonverbal signals indicating the desire to donate. Between nonverbal signals, which are almost inherently ambiguous, and verbal ones, the law must look to the verbal indicators. ${ }^{107}$

A structural analysis of this change indicates that the elements of the crime will not change. The actus reus remains the act of having intercourse with a person without that person's consent. The mens rea does not change either; it remains an intent to have intercourse without consent, or recklessness as to consent. The onus remains on the Crown to prove the absence of consent. The only difference is that consent is given a legislated meaning. What constitutes consent has always been a difficult concept for the courts to wrestle with, not only in cases of sexual assault, but also in other types of assault as well. ${ }^{108}$ The inclusion of a definition of consent/non-consent attempts to make clear the kinds of activity which are considered to be adequate expressions of consent.

It could be argued that a definition of consent cannot reflect the reality of the different ways consent can be communicated. However, I would suggest that it can be a reasonable effort at conveying what society in general considers to be the appropriate level of communication. In the context of the everyday situation, it does not appear to be unreasonable to suggest that a man endeavour to discover if a partner is consenting, nor is it unreasonable to expect him to base his actions on a clearly defined response. If he misreads this response as a negative, when it is positive, no harm is done, as the other party can then make her wishes known. The proposed legislation reflects this position in s. 273.2(b):

It is not a defence to a charge under sections 271,272 or 273 that the accused believed that the complainant consented to the activity that formed the subject-matter of the charge, where

(b) the accused did not take all reasonable steps, in the circumstances known to the accused at the time, to ascertain that the complainant was consenting.

This looks like a variation on the defence of due diligence, and this raises the issue of whether the section would be considered constitutional by the courts. In Hess v. R.; Nguyen v. $R .{ }^{(1)}{ }^{(*)}$ Wilson, J. addressed the constitutionality of s. 146(1) of the Criminal Code, an offence which prohibits sexual intercourse with a female under the age of fourteen. The section expressly removed the defence of mistake of fact as to the age of 
the female. Wilson, J. canvassed the law and held that a criminal offence punishable by imprisonment must have a mens rea component. Based on the cases of $R$. v. Sault Ste Marie $^{110}$ and B.C. Motor Vehicle Act, ${ }^{11}$ there can be no absolute liability offence that risks criminal sanction. The category of strict liability offenses, as defined in Sault Ste. Marie, was generally assumed to be one of regulatory offenses, where a defence that the accused took all the reasonable steps to ensure compliance with the law was considered to be the only available defence to a breach. While stating that s. 146(1) cannot be saved under s. 1 of the Charter, Wilson, J. adverts to the modification of the section now in the Code. The modification is that an accused must have made reasonable efforts to determine if the female was under fourteen. She categorizes this as a due diligence defence and suggests that it is a more appropriate legislative attempt at regulating offenses against children. However, she stops short of saying whether the new section infringes s. 7 of the Charter, or whether if it does, it could be saved under s. 1 .

The formulation in s. 273.2(b) relates to the availability of the honest but mistaken belief in consent. The defence is only available where the accused has made a reasonable effort to determine if there is consent. The section has both objective and subjective elements: the test is one of reasonableness, but reasonability given the circumstances known to the accused at the time. The issues raised here are slightly different than in the case of s. 146(1), because the defence in the latter is restricted to due diligence while in the former, the defence of honest but mistaken belief remains available, subject to due diligence. However, analysis of the section suggests this distinction may, in fact, be a very fine one. It requires that the accused must have at least addressed his mind to the issue of consent. This is already a requirement as the law now stands. As Dickson, J. pointed out in Pappajohn, recklessness as to consent is an element of the mens rea requirement. The inclusion of making a reasonable effort to determine if there is consent may be seen as no more than another way of saying that a mistaken belief in consent must be reasonable. In the same way, a reasonable attempt to determine if a female is under fourteen when she is not is, in fact, a reasonable mistaken belief. The only difference is that the inclusion of a due diligence defence creates a reverse onus on the accused to prove he made a reasonable attempt. Given the reluctance of the court to accept reasonableness as a requirement, the addition of a reverse onus is even less likely to succeed.

Section 273.2(a) lists two other limitations on the honest but mistaken belief, selfinduced intoxication and recklessness and wilful blindness. These limitations were, arguably, already part of the law. ${ }^{112}$ The definition of consent, in itself, will presumably limit the defence of honest but mistaken belief. Most mistaken beliefs will become mistakes of law and, therefore, will not constitute a justification for the act. Where a party bases his belief in consent in a form of consent that is not contemplated in the definition, this is a mistake of law: where his mistake is based on a misreading of the

112. See Pappajohn, supra, note 88; Sansregret v. R., [1985] 1 S.C.R.570, [1985] 3 W.W.R. 701, 18 C.C.C.(3d) 223, 35 Man. R. (2d) 1, 17 D.L.R. (4th) 577. 
complainant's response, the honest but mistaken belief in consent defence may remain. The apparent purpose of section 273.2 is to limit its availability further by making it clear that it will not be available where the belief arose as a result of the accused's own intoxication or recklessness, and there need not be a requirement of reasonableness to limit the admission of irrelevant sexual history evidence. The reasonableness requirement will not be within the defence but will be an inherent aspect of the definition. To prove an honest but mistaken belief, the accused would have to show, given the definition of consent, an air of reality to his belief that the complainant's response was consent for the purposes of the definition.

Whether evidence going to similar facts and motive to fabricate would legitimately involve evidence of sexual conduct with persons other than the accused, would depend on the court's approach to the legislature's intent. If it were to accept the communicative model of sexuality proposed by Murthy, it is likely that most of this evidence would not be considered relevant.

The specific instances of conduct offered as evidence coupled with the situation in question, must be part of the woman's communication of consent to sexual intercourse grounded in a realistic notion of why the woman would consent. 11.3

However, if the basis of consent remains the contractual model as identified by Murthy, then including a definition of consent is unlikely to change the perception that previous sexual conduct is evidence of, either, a pattern that would indicate consent or a motive to fabricate. Based on a communicative model, the fact that a woman enjoyed rough sex before could not be taken to indicate consent now. A contractual model, not withstanding a definition of consent, could still rely on the past conduct to indicate that there was consent or bias.

The proposed "rape shield" provisions in s. 276 attempt to address the problems raised in both the majority and dissenting judgments in Seaboyer. The section prohibits the admission of sexual history evidence solely for the purpose of showing that the complainant was more likely to have consented or is less worthy of belief. It also requires that the evidence must be relevant to an issue to be proved at trial, and that it must have significant probative value that is not "outweighed by the danger of prejudice to the proper administration of justice." It further mandates that in determining relevance and probative value, the judge must consider such factors as the accused's right to make full answer and defence, society's interest in the reporting of crime, the importance of eliminating any discriminatory belief or bias from the fact finding process, the risk that the evidence will arouse the jury's sentiments of prejudice, sympathy or hostility, the possible prejudice to the complainant's privacy and dignity, and the right of all persons to personal security and protection and benefit of the law. The section is clearly an attempt to balance the competing interests of the complainant and of the accused and to address the concerns of the majority in regards to judicial discretion and the dissent in regards to distortion of the trial process due to bias and stereotype. 


\section{CONCLUSION}

The problem of reconciling modern understanding and recognition of the myths and stereotypes underlying rape law with the traditional legal structure and theoretical underpinnings of the criminal justice system is unlikely to be solved by the use of rape shield laws. They were a necessary first step in making clear how the rules of evidence operated to the disadvantage of women, and they revealed the underlying gender bias of the legal structure. The problem is that they do not accord well with the requirements of judicial discretion. While recognizing the inherent limitations and uncertainties associated with judicial discretion, it is clear that blanket exclusions cannot be constitutional. What is required are changes, both in the Criminal Code and in the perspective from which the judiciary examines the questions of sexual assault. The criminal law not only reflects society's perceptions of morality, it also has a function in shaping society's beliefs, ${ }^{114}$ and it is important that this function be exercised in a way that promotes the values that underlie the Charter of Rights. These values include not only the protection of the rights of the accused but also the values of equality, and security of the person, and the integrity of the justice system as a whole. 